\title{
Comportamento de plântulas de Laelia tenebrosa Rolfe (Orchidaceae), inoculadas in vitro sob diferentes substratos
}

\author{
Behavior of Laelia tenebrosa (Orchidaceae) seedlings in vitro inoculated \\ in different substrates
}

\author{
Gustavo Sessa Fialho ${ }^{1}$; Julio César DoVale ${ }^{1}$; Fabricio Moreira Sobreira ${ }^{1}$; Edilson Romais Schmildt ${ }^{2}$
}

\begin{abstract}
RESUMO
O presente trabalho objetivou estudar o desenvolvimento in vitro de plântulas de Laelia tenebrosa Rolfe frente a diferentes substratos umedecidos com solução nutritiva. Os tratamentos foram: T1 (testemunha) - Solução nutritiva solidificada com 6 g.L.-1 de agar; T2 - Vermiculita; T3 - fibra rizomatosa moída de Pteridium aquilinum Kuhn. Para os tratamentos T2 e T3 utilizou-se 1L de solução nutritiva para umedecer $300 \mathrm{~g}$ dos referidos substratos. O experimento foi conduzido no laboratório de biotecnologia do Centro de Ciências Agrárias da Universidade federal do Espírito Santo onde plântulas previamente germinadas in vitro foram inoculas em frascos com capacidade de $250 \mathrm{~cm}^{3}$ contendo para $\mathrm{T} 1-50 \mathrm{~mL}$ por frasco e para $\mathrm{T} 2 \mathrm{e} \mathrm{T} 3-15 \mathrm{~g}$ por frasco dos referidos substratos. O delineamento experimental foi inteiramente casualizado (DIC) com quatro repetições de quatro plantas cada. Após 180 dias avaliou-se a altura das plântulas, o número de folhas e o peso da matéria fresca. Para altura das plântulas e número de folhas não houve diferença significativa entre as médias dos tratamentos. Contudo, quando avaliou-se peso da matéria fresca T1 mostrou-se superior a T3 por incrementar em média 58,5 mg no peso da matéria fresca por plântula.
\end{abstract}

Palavras-chave: Laelia tenebrosa Rolfe, Orchidaceae, desenvolvimento in vitro.

\begin{abstract}
This research studied in vitro development of Laelia tenebrosa Rolfe seedlings under different substrates watered with a nutrient solution. The nutrient solution was the same for all treatments: MS liquid medium $+2 \mathrm{mg}$ of BAP per liter $+0.1 \mathrm{mg}$ of AIA and pH adjusted to $5.8 \pm 1.0$ before autoclaving at $121^{\circ} \mathrm{C}, 1 \mathrm{~atm}$. for 20 minutes. The evaluated treatments were: T1 - nutrient solution + $6 \mathrm{~g}$ of agar per liter, T2 - nutrient solution + vermiculite and T3 - nutrient solution + rhizome fiber of Pteridium aquilinum Kuhn. The experiment was conduced in a completely randomized design, with 4 seedlings per replicate. When the seedlings reached an average height of $1 \mathrm{~cm}$ they were sub-cultivated in a $250 \mathrm{~cm}^{3}$ bottle containing: $T 1-50 \mathrm{~mL}$ nutrient solution $+6 \mathrm{~g}$ agar per liter; T2 - $15 \mathrm{~g}$ nutrient solution + vermiculite and T3 - $15 \mathrm{~g}$ nutrient solution + rhizome fiber of Pteridium aquilinum Kuhn. Each gram of substrate of T2 and T3 was watered with $5 \mathrm{ml}$ of nutrient solution. After 180 days of seedling sub-cultivation the following parameters were evaluated: height of aerial part, leaf number and total fresh mass. There was no significant difference between the treatment means for aerial height or leaf number. However, when weight of the fresh mass was evaluated, T1 was superior to T3; it showed an increase of $58.5 \mathrm{mg}$ on the average in the weight of the fresh mass of seedlings.
\end{abstract}

Key words: Laelia tenebrosa Rolfe, Orchidaceae, in vitro development.

\section{Introdução}

As orquídeas são plantas muito almejadas por apresentarem inflorescências grandes, volumosas e coloridas. No planeta existem cerca de 35.000 espécies distribuídas em seis tribos, 80 subtribos e 750 gêneros (Heywood, 1993; Blossfeld, 1999). Atualmente algumas destas espécies vêm sendo ameaçadas de extinção quer seja por práticas extrativistas ou pela devastação de seus habitats naturais (Colombo et al., 2004). Neste contexto, enquadra-se a Laelia tenebrosa Rolfe, que vegeta

\footnotetext{
1 Eng. Agr ${ }^{\circ}$., doutorando, Dept ${ }^{\circ}$ Fitotecnia/Universidade Federal de Viçosa (UFV), Viçosa-Minas Gerais - Brasil, CEP: 36570-000, gsfialho@hotmail.com

2 Prof. Adjunto, Dept $^{\circ}$ de Ciências da Saúde, Biológicas e Agrárias, CEUNES/UFES, São Mateus-ES, Brasil.
} 
principalmente nos remanescentes de mata atlântica do Espírito Santo e Rio de Janeiro, Estados brasileiros (Ruschi, 1986). A referida espécie encontra-se na lista de plantas ameaçadas de existinção do Instituto Brasileiro do Meio Ambiente e dos Recursos Naturais Renováveis (IBAMA).

Segundo Faria et al. (2006), As orquídeas apresentam desenvolvimento vegetativo vagaroso, visto que a propagação por divisão de touceira leva, no mínimo, dois anos, o que torna lenta e onerosa a multiplicação em grandes quantidades para a comercialização de mudas. A propagação de orquídeas por sementes também é demorada e das milhões de sementes produzidas em uma cápsula, somente 5\% germinam. A cultura de células e tecidos vegetais tem contribuído grandemente para o desenvolvimento da orquidocultura, onde o cultivo em meio nutritivo, utilizando técnicas especiais, têm permitido acelerar esse processo e elevar a taxa de germinação, tornando o processo de multiplicação de orquídeas viável (Stancato e Faria, 1996).

O ágar é o agente gelificante mais utilizado na propagação in vitro, pela sua grande eficiência como promotor de condições ideais de suporte para as plântulas (Waes, 1987; Stancato e Faria, 1996; Faria et al., 2002). Todavia, ele também é o componente mais oneroso do meio de cultura. De acordo com Grattapaglia e Machado (1998), há uma tendência mundial de se buscarem sistemas utilizando meio líquido, em virtude da redução do custo pela eliminação do ágar e da maior agilidade na preparação do meio de cultura.

Desta forma, para a espécie supracitada, estudos referentes à sua multiplicação e desempenho in vitro frente a estruturadores físicos do meio de cultura que sejam mais baratos que o ágar, revestem-se de grande importância visto que podem corroborar com a propagação destas plantas em escala que permita sua reintrodução na natureza a custos reduzidos.

O presente trabalho objetivou estudar a influência de diferentes substratos no desenvolvimento in vitro de plântulas de Laelia tenebrosa, bem como analisar o seu comportamento, de modo a contribuir com informações relevantes que possam auxiliar na luta contra seu futuro desaparecimento.

\section{Materiais e Métodos}

O experimento foi conduzido no laboratório de biotecnologia do Centro de Ciências Agrárias da Universidade federal do Espírito Santo (CCAUFES), localizado no município de Alegre/ES, latitude $20^{\circ} 45^{\prime}$ Sul, longitude $41^{\circ} 48^{\prime}$ Oeste e altitude de $150 \mathrm{~m}$.

Como base comum para a confecção do meio de cultura, utilizou-se solução nutritiva de sais MS (Murashige e Skoog, 1962), suplementada com 2 mg. L $^{-1}$ de BAP, $0,1 \mathrm{mg} . \mathrm{L}^{-1}$ de AIA e pH ajustado para $5,8 \pm 1,0$ antes da autoclavagem a $121^{\circ} \mathrm{C}$, $1 \mathrm{~atm}$ por 20 minutos. Os tratamentos foram: T1 (testemunha) - Solução nutritiva solidificada com 6 g.L.-1 de agar; T2 - Vermiculita; T3 - fibra rizomatosa moída de Pteridium aquilinum Kuhn. Tanto para os tratamentos T2 e T3 utilizou-se $1 \mathrm{~L}$ de solução nutritiva para umedecer $300 \mathrm{~g}$ dos referidos substratos. Plântulas com aproximadamente $1,5 \pm 0,5 \mathrm{~cm}$ de comprimento, oriundas de germinação in vitro, foram inoculadas em frascos com capacidade de $250 \mathrm{~cm}^{3}$ contendo para $\mathrm{T} 1-50 \mathrm{~mL}$ por frasco e para T2 e T3 $-15 \mathrm{~g}$ por frasco dos referidos substratos. Após a inoculação em câmara de fluxo laminar os frascos foram transferidos para sala de cultivo a $25 \pm 2{ }^{\circ} \mathrm{C}$, intensidade luminosa de $35 \mu \mathrm{M} \cdot \mathrm{m}^{-2} \cdot \mathrm{s}^{-1}$ e fotoperíodo de 16 horas.

Utilizou-se o delineamento inteiramente casualizado (DIC), com quatro repetições de quatro plântulas cada. Decorridos 180 dias, como variáveis para a análise do desenvolvimento, avaliou-se a altura das plântulas, o número de folhas e o peso da matéria fresca. Utilizando-se para tal, régua milimetrada e balança analítica de precisão $(0,0001)$.

Os dados foram submetidos à análise de variância, sendo as médias comparadas pelo teste de Tukey em nível de 5\% de probabilidade, utilizando-se o aplicativo computacional em genética e estatística, denominado programa GENES (Cruz, 2006).

\section{Resultados e Discussão}

Os resultados obtidos para as variáveis analisadas encontram-se abaixo divulgados na Tabela 1.

De modo geral, a espécie Laelia tenebrosa Rolfe mostrou excelente performance in vitro, com boa taxa de crescimento e produção de folhas.

Para as variáveis altura das plântulas e número de folhas não houve diferença significativa entre as médias dos tratamentos (Tabela 1), indicando que tanto a vermiculita quanto a fibra rizomatosa de Pteridium aquilinum Kuhn apresentaram efeito semelhante ao do ágar sobre as referidas variáves. Todavia, quando avaliamos o peso da matéria fresca 
Tabela 1. Altura das plântulas, número de folhas e peso da matéria fresca medidas em Laelia tenebrosa Rolfe aos 180 dias a pós a inoculação in vitro sob diferentes substratos, CCA-UFES, Alegre- ES

\begin{tabular}{lccc}
\hline Tratamentos & Altura das plântulas & Numero de folhas & Matéria fresca \\
\hline $\begin{array}{l}\text { T1 - Solução nutritiva } \\
\text { solidificada com 6 } \\
\text { (g.L-1) de ágar }\end{array}$ & $1,7125 \mathrm{a}$ & $4,75 \mathrm{a}$ & $0,0824 \mathrm{a}$ \\
T2 - Vermiculita & $1,0375 \mathrm{a}$ & & $0,0549 \mathrm{ab}$ \\
$\begin{array}{l}\text { T3 - fibra de Pteridium } \\
\text { aquilinum Kuhn }\end{array}$ & $0,9438 \mathrm{a}$ & $4,50 \mathrm{a}$ & $0,0239 \mathrm{~b}$ \\
\hline
\end{tabular}

Médias seguidas de mesma letra, na coluna, não diferem estatisticamente entre si pelo teste de Tukey a 5\% de probabilidade.

das plântulas somente diferiram significativamente entre si as médias dos tratamentos T1 (solução nutritiva solidificada com 6 g.L $\mathrm{L}^{-1}$ de ágar) e T3 (fibra rizomatosa de Pteridium aquilinum Kuhn), onde o efeito de T1 sobre a variável em questão igualouse ao de T2 (vermiculita) e mostrou-se superior a T3 por incrementar em média $58,5 \mathrm{mg}$ no peso da matéria fresca por plântula (Tabela 1). O que reafirma a explanação de Grattapaglia e Machado (1998): "substratos inertes, como a vermiculita, a perlita ou espumas de poliuretano, embebidas em meio liquido, podem ser alternativas de menor custo que o Agar".

\section{Conclusão}

- Os diferentes substratos, não influenciaram no número de folhas e na altura das plântulas testadas.

- Para o peso da matéria fresca o melhor tratamento foi T1 - Solução nutritiva solidificada com 6 g.L. L $^{-1}$ de ágar e T2 $(15 \mathrm{~g}$ por frasco de vermiculita umedecida com $50 \mathrm{ml}$ de solução nutritiva).

- A vermiculita pode ser utilizada em substituição ao ágar como agente estruturador de meio de cultura.

\section{Literatura Citada}

Blossfeld, A.

1999 Orquidologia, Orquidofilia e Orquicultura. Jaboticabal: FUNESP, $89 \mathrm{p}$.

Colombo, L. A.; Faria, R. T.; Carvalho, J. F. R. P.; Assis, A. M.; Fonseca, I. C. B.

2004 Influência do fungicida clorotalonil no desenvolvimento vegetativo e no enraizamento in vitro de duas espécies de orquídeas brasileiras. Acta Scientiarum (UEM), Maringá, 26 (2): 253-258.

Cruz, C. D. 2006. Programa GENES: estatística experimental e matrizes. Editora UFV: Viçosa, $480 \mathrm{p}$.

Faria, R. T.; Dalio, R. J. D.; Unemoto, L. K. ; Silva, G. L. 2006 Propagação in vitro de Oncidium baueri Lindl. (Orchidaceae) sem uso de ágar. Acta Scientiarum (UEM), Maringá, 28 (1): 71-74.

Faria, R. T.; Santiago, D. C.; Saridakis, D. P.; Albino, U. B.; Araújo, R.

2002 Preservation of the brazilian orchid Cattleya walkeriana Gardner using in vitro propagation. Crop breeding and applied biotechnology, Viçosa, 2 (3): 489-492.
Grattapaglia, D.; Machado, M.A. 1998 Micropropagação. In: Torres, A.C.; Caldas, L. S. (Ed.). Cultura de tecidos e transformação genética de plantas. Brasília: Embrapa-SPI, pp. 183-260.

Heywood, V.H. 1993. Flowering plants of the world. London: B.T. Batsford, 335 p.

Murashige, T.; Skoog, F.

1962 A revised medium for rapid growth and bioassays with tobacco tissue cultures. Phisiol. Plant., Copenhagem, 15 (3): 473-479.

Ruschi, A.

1986 Orquídeas do Espírito Santo. Rio de Janeiro: Expressão e Cultura, $278 \mathrm{p}$.

Stancato, G.C.; Faria, R.T.

1996 In vitro growth and mineral nutrition of the lithophytic orchid Laelia cinnabarina Batem. (Orchidaceae) I: effects of macro and microelements. Lindleyana, West Palm Beach, 11 (1): 41-43.

Waes, J.

1987 Effects of activated charcoal on in vitro propagation of western European orchids. Acta Horticulturae, The Hague, 212: 131-138. 

ANDROS IMPRESORES

Www.androsimpresores.cl 
